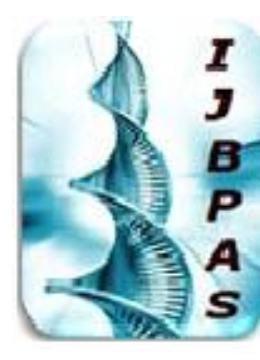

International Journal of Biology, Pharmacy and Allied Sciences (IJBPAS) 'A Bridge Betuen Caboratory and Q Qunder' WWw.iibpas.com

\title{
SINGLE CELL PROTEIN POTENTIAL OF FUNGI ASSOCIATED WITH VERMICAST USING BANANA FRUIT PEEL AS SUBSTRATE
}

\section{SIMON, MA. LYN H., UNDAN, JERWIN R., AND VALENTINO, MARY JHANE G.}

Department of Biological Sciences, College of Arts and Sciences, Central Luzon State University, Science City of Munoz, Nueva Ecija, Philippines

*Corresponding author: E Mail: malynsimon14@gmail.com

Received 22 ${ }^{\text {nd }}$ April 2018; Revised 30 ${ }^{\text {th }}$ May . 2018; Accepted 20 ${ }^{\text {th }}$ June 2018; Available online $1^{\text {st }}$ July 2018

\section{https://doi.org/10.31032/IJBPAS/2018/7.7.4505}

\section{ABSTRACT}

The potential of four fungi associated with vermicast namely; Aspergillus niger, Rhizopus stolonifer, Aspergillus fumigatus and Rhizo mucorpusillus as sources of single cell protein using banana fruit peel as substrate was evaluated in the present study. After 20 days of SSF, the proximate compositions of banana fruit were affected wherein both increment and reduction were recorded. Results showed that among the four fungi tested, A. niger and $R$. Stolonifer are the best for the production of single cell protein which led to significant increase in the crude protein content of banana fruit peel and caused the reduction in moisture content, increase in ash content, crude fiber and crude fat of the substrate.

\section{Keywords: banana fruit peel - crude protein - fungi}

\section{INTRODUCTION}

Banana is one of the most important and common agricultural crops grown in almost all tropical countries $\left[\begin{array}{ll}1, & 2\end{array}\right]$. Meanwhile, vast production of banana also leads to tons of banana fruit peel as waste. Banana fruit peel is proven to have medicinal properties and various industrial applications of banana fruit peel such as bio-fuel production, bio-sorbents, pulp and paper, cosmetics, energy related activities, organic fertilizer, environmental clean-up and biotechnology related process has already been explored [3, 4]. Accordingly, vitamins, minerals, source of starch, crude protein, 
crude fat, polyphenols, carotenoids which can be attributed to its and antioxidant properties of banana fruit peel $[5,6]$.

This present study, aimed to enhance the nutritional attributes of banana fruit peel by enriching with fungal organisms isolated from vermicast which would lead further to utilization of both substrate and the fungal isolates. Microorganisms vary greatly from one to another in their ability to produce enzymes [7, 8].Fungi are also used to produce industrial chemicals, including citric, malic and lactic acids and industrial enzymes such as lipase, cellulase and amylase [9].Thus the conversion of biodegradable and underutilized waste into a useful substrate as source for the additional proteins produced by the fungi which would help us to be free from animal food deficiency and helps solve the global food scarcity and deficiency successfully.

\section{MATERIALS AND MATHODS}

The production for single cell protein was carried out following the procedures of Ganado et al, [10] Valentino et al [11] with some modifications

\section{Preparation of fungal inoculants and subtrates}

The fungal isolates were obtained from the collection of fungi associated with vermicast. After which, these were sub cultured using a Potato dextrose agar.

Meanwhile for the preparation of substrate, banana fruit peels were washed cut into small pieces and was sun dried. Then it was pulverized using an osteorizer. One hundred (100) grams of dried banana fruit peel was placed in wide mouth culture bottles and distilled water was added to the substrate to obtain $60-65 \%$ moisture content. It was then covered with plastic and sterilized at 15 psi at $121^{\circ} \mathrm{C}$ for 30 minutes.

\section{Solid State fermentation}

Sterilized substrates were inoculated with a 10-mm-diameter of fungal mycelia. Then it was covered with plastic and were allowed to ramify for 20 days at room temperature. After which, the culture was sterilized at $15 \mathrm{psi}$ at $121^{\circ} \mathrm{C}$ for 1 hour and was air dried for seven days. The proximate composition of the fungal enriched banana fruit peel were determined at Lipa Quality Control Center, Bocaue Bulacan. Data were analyzed using analysis of Variance, and means were compared with T-test.

\section{RESULTS and DISCUSSIONS}

This study was conducted to determine the potential of fungi associated with vermicast namely: Aspergillus niger, Rhizopus stolonifer, Aspergillus fumigatus and Rhizo mucorpusillus in the production of 
single cell protein by increasing the crude protein content of the banana fruit peel and the proximate composition of fungal enriched banana fruit peel.

\section{Crude Protein Content}

Results showed that $R$. stolonifer treated banana fruit peel had the highest CPC of $6.29 \%$ followed by $A$. niger treated banana fruit peel of $5.88 \%$. Whereas reduction in CPC was observed when banana fruit peel were treated with $R$. pusillus and $A$. fumigatus with $4.14 \%$ and $4.05 \%$. Additionally, for the percentage increase in CPC, only $R$. stolonifer and A. niger registered percentage increment of $10.73 \%$ and $3.52 \%$, respectively and reduction of $28.64 \%$ and $-27.11 \%$ when treated with $A$. fumigatus and $R$. pusillus were recorded. These coincides with several studies involving $R$. stolonifer [12] which is caused by the ability of fungal organisms to secrete enzymes in the likes of amylases, xylanases, cellulases; hydrolytic activities and increased fungal biosynthesis $[13,14]$. Also, utilization of starch as carbon source which caused hydrolysis of starch to glucose and could cause synthesis of fungal biomass. [15, 16, 17]. Meanwhile, the crude protein content is influenced by the mount of nitrogen present and the fungal growth in the banana fruit peel[ $[18,19]$.
Moisture, Ash, Crude Fat and Crude Fiber Content of Fungal Enriched Banana Fruit Peel

Proximate composition of the treated and untreated banana fruit peel was also evaluated including the moisture content, ash content, crude fat content and crude fiber content. Table 3, shows the corresponding values for the proximate composition of the banana fruit peel treated fungi.

For the moisture content, A. fumigates treated banana fruit peel obtained the highest moisture of $38.62 \%$ followed by $R$. pusillus treated banana fruit peelof36.34\%, whereas, A. niger and $R$. stolonifer treated banana fruit peel had the lowest moisture content of $13.60 \%$ and $12.37 \%$, respectively. The change in moisture content is indicative of the proteolytic activity of the tested fungal organisms [20, 21, 22].

Meanwhile, the highest ash content was noted in $A$. niger treated banana fruit peel with $12.30 \%$ followed by $R$. Stolonifer treated banana fruit peel with $12.01 \%$ while R. fumigatus and R. Pusillus treated banana fruit peel recorded $8.35 \%$ and $8.28 \%$ (Table 3).High amount of ash is proportional to the amount of macrominerals in banana fruit peel and it is inversely proportional to the reduced amount of organic compounds during 
bioconversion process $[23,24,25,26,27$, 28].

Evaluation of crude fat content of fungal treated banana fruit peel showed that $R$. stolonifer treated banana fruit peel had the most crude fat content with $12.43 \%$ followed by $A$. niger treated banana fruit peel with $11.21 \%$ while A. fumigatus and $R$. pusillus treated banana fruit peel had the least fat content with $7.90 \%$ and $7.88 \%$ (Table 3).Reduction in crude fat, is due to the production of lipolytic enzymes by the fermenting organisms which hydrolyzed fats in the sample to glycerol and fatty acids[29, 30].

Finally for the crude fiber content, $R$. Stolonifer treated banana fruit peel had the highest fiber content with $12.81 \%$, and reduced crude fiber content were noted in $A$. niger treated banana fruit peel with $10.61 \%$, R. pusillus and A. fumigatus treated banana fruit peel with $9.32 \%$ and $8.32 \%$, respectively. The increase of crude fiber can be attributed to the synthesized fiber by microorganisms [31, 32] while the decreased in crude fiber contents could be attributed to the excretion of extracellular enzymes for degrading fibers [33]. Also, synergistic interactions due to secretion of various enzymes that degrade complex polysaccharides resulted to the observed change in the amount of crude fiber content [34].

In totality, A.niger and R. stolonifer increased the crude protein content of the banana fruit peel which led to the decrease in moisture, increase in ash content, crude fiber and crude fat. Meanwhile, A. fumigatus and R.pusillus caused the reduction of the crude protein content of the substrate which corresponds to the increase of moisture, reduction in ash, crude fiber and crude fat.

Table 1: Crude protein content of fungi treated banana fruit peel

\begin{tabular}{|c|c|c|}
\hline Treatments & "Crude Protein Content & $\begin{array}{c}\text { \% Change in Crude Protein } \\
\text { Content }\end{array}$ \\
\hline Control (Uninoculated banana peel) & 5.68 & \\
\hline A. niger- treated banana fruit peel & $5.88^{\text {ns }}$ & 3.52 \\
\hline R. stolonifer-treated banana fruit peel & $6.29^{\mathrm{ns}}$ & $10.73^{\mathrm{ns}}$ \\
\hline A. fumigatus- treated banana fruit peel & $4.05^{*}$ & $-28.64^{*}$ \\
\hline R. pusillus- treated banana fruit peel & $4.14^{\mathrm{ns}}$ & $-27.11^{\mathrm{ns}}$ \\
\hline
\end{tabular}

*Significantly different **Highly significantly different ns- no significant difference

Table 2: Mean percentage of proximate composition of enriched banana fruit peel

\begin{tabular}{|c|c|c|c|c|}
\hline Treatments & Moisture & Ash & Crude fat & Crude fiber \\
\hline Control (Uninoculated banana fruit peel) & 13.87 & 11.46 & 11.00 & 11.17 \\
\hline A. niger-treated banana fruit peel & $13.60^{\mathrm{ns}}$ & $12.30^{\mathrm{ns}}$ & $11.21^{\mathrm{ns}}$ & $10.61^{*}$ \\
\hline R. stolonifer - treated banana fruit peel & $12.37^{*}$ & $12.01^{\mathrm{ns}}$ & $12.43^{*}$ & $12.81^{\mathrm{ns}}$ \\
\hline A. fumigatus- treated banana fruit peel & $38.62^{* *}$ & $8.35^{*}$ & $7.88^{*}$ & $8.32^{*}$ \\
\hline R. pusillus- treated banana fruit peel & $36.34^{* *}$ & $8.28^{*}$ & $7.90^{*}$ & $9.32^{\text {ns }}$ \\
\hline
\end{tabular}




\section{CONCLUSION}

Based on the results of the study it can be concluded that $R$. Stolonifer and $A$. niger significantly increased the crude protein of banana fruit peel, thus their potentials as source of single cell protein.

\section{REFERENCES}

[1] Enein, A. B. M., Salama, Z. A, Gaafar, A. A., Aly, H. F., Elella, F. A. B. \& Ahmed, H. A. (2016). Identification of phenolic compounds from banana peel (Musa paradaisica L.) as antioxidant and anti-microbial agents. Journal of Chemical and Pharmaceutical research, 8(4), 4655.

[2] Wachirisari, P., Julakarangka S. \& Wanlapa, S. (2009). The effects of banana peel preparations on the properties of banana peel dietary fiber concentrate. Songklanakarin Journal of Science and Technology, 31(6), 605-611.

[3] Ehiowemwenguan, G., Emoghene, A. O. \& Inetianbor, J. E. (2014). Antibacterial and phytochemical analysis of banana fruit peel. Journal of Pharmacy, 4(8), 18-25.

[4] Yousaf, M. M. \& Sajjad, S. (2015). Application of thermally and chemically modified banana peels waste as adsorbents for the removal of iron from aqueous system. Journal of Environmental Analytical Chemistry, 2(3), 1-12.

[5] Mohapatra, D., Mishra, S. \& Sutar, N. (2010). Banana and its by-product utilization: An overview. Journal of Scientific and Industrial Research, 69, 323-329.

[6] Mauludin, G. R., Cahyani, I. W., Apriliani, D. S. \& Ariel, D. G. (2017). "Fame" (Fruit Face Mask Essentials): Organic face mask made from banana peel waste. International Malaysia-Indonesia-Thailand, 3, 1- 4.

[7] Waiter, M. J., Morgan, N. L., Rockey, J. S \& Higton, G. (2007). Microbial enzymes. In. industrial microbiology (1st edition.). Blackwell publishing, New Delhi, 113-114.

[8] Geethanjali, P. A. \& Reshma, K. (2014). Potentiality of soil fungi to produce protease through solid substrate fermentation technique. International Journal of Emerging Engineering Research and Technology,2(4), 327-332.

[9] Mittal. P. (2018). List of Fungi Benefits. https://sciencing.com/listfungi-benefits-8606974.html 
[10] Ganado, L. S., Undan, J. R. \& Valentino, M. J. G. (2016). Proximate composition and cytotoxicity of single cell protein enriched rich bran. Current Research in Environmental \& Applied Mycology, 6 (2), 102-110.

[11] Valentino MJG, Kalaw SP, Galvez CT \& Reyes RG. (2015). Mycota of distillery yeast sludge as source of single cell protein. Mycosphere 6 (3): 241-247.

[12] Alemawor, F., Dzogbefia, V. P., Emmanuel, O. K., Oddoye \& Oldham, J. H. (2009). Effect of Pleurotus ostreatus fermentation on cocoa pod husk composition: Influence of fermentation period and $\mathrm{Mn} 2+$ supplementation on the fermentation process. African Journal of Biotechnology, 8(9), 1950-1958.

[13] Raimbault, M. (1998). General and microbial aspects of solid substrate fermentation. Journal of Biotechnology, 1(3), 1-15.

[14] Yuan Zhu, Z., Li, Y., Sun, H., Chen, L. J., Tang, Y. L, Cui Liu, X. \& Zhang, Y. M. (2014). Screening of Cordyceps strains and optimization of its solid-state fermentation conditions on bioconversion of
Astragalusresidue.

Cellulose

Chemistry and Technology, 50 (2), 257-263.

[15] Samadi, S., Mohammadi, M. \& Najafpour, G. D. (2016). Production of single cell protein from sugarcane bagasse by Saccharomyces cerevisiae in tray bioreactor. International Journal of Engineering, 8(29), 1029-1036.

[16] Hammond, J. W. B. \& Wood, D. A. (1985). Metabolism, Microbiology. In: The biology and technology of the cultivated mushrooms, second edition. Research Journal of Microbiology, 6(1), 63-70.

[17] Akinfemi, A. (2012). Upgrading of sugarcane bagasse by solid state fermentation with Pleurotus sajorcaju and Pleurotus florida and the impact on the chemical composition in vitro digestibility. Biotechnology in Animal Husbandry, 28 (3), 603-611.

[18] Kurniati, T., Nurlaila, L. \&Iim. I. (2017). Effect of inoculum dosage Aspergillus niger and Rhizopus oryzae mixture with the fermentation time of oil seed cake (Jatropha curcas L) to the content of protein and crude fiber. Journal 
of Physics: Conference series,824, $1,1-9$.

[19] Mirnawati., Y. Ciptaan, G. \& Ferawati, M. (2017). The effect of mannanolytic fungi and humic acid dosage to improve the nutrient content and quality of fermented palm kernel cake. International Journal of Chemical Technology Research, 3(10), 32-37.

[20] Anihouvi, V. B., Kpoclou, E. Y. \& Hounhouigan J. D. (2012). Use of starter cultures of Bacillus and Staphylococcus in the controlled fermentation of lanhouin, a traditional fish-based condiment from West African. African Journal of Microbiology, 6, 4767-4774.

[21] Hammoumi, A., Faid, M., El Yachioui, M. \&Amarouch, $H$. (1997). Characterization of fermented fish waste used in feeding trials with broilers. Process Biochemistry, 33, 423-427.

[22] Khodanazary, A., Hajimoradloo, A. \& Ghorbani, R. (2013). Influence of solid-state fermentation on nutritive values and enzymatic activities of anchovy kilka (Clupeonellaengrauli formis svetovidov, 1941) meal by using different microorganisms.
International Research Journal of Applied and Basic Sciences, 4 (8), 2357-2367.

[23] Zadrazil, F., Punyia, A. K. \& Singh, K. (1995). Biological upgrading of feed and feed components. Biotechnology in Animal Feeds and Animal Feeding, 55-70.

[24] Jalc, D., Siroka, P., Fejes, J. \&Eresakova, Z. (1999). 31 it of three strains of Pleurotus tuberregium(Fr.) singer on chemical composition and rumen fermentation of wheat straw. Journal of General Applied Microbiology, 45, 277-282.

[25] Alemawor, F., Dzogbefia, V. P., Emmanuel, O. K., Oddoye\& Oldham, J. H. (2009).Effect of Pleurotus ostreatus fermentation on cocoa pod husk composition: Influence of fermentation period and $\mathrm{Mn} 2+$ supplementation on the fermentation process. African Journal of Biotechnology, 8(9), 1950-1958.

[26] Okareh, O. T., Adeolu, A. T. \& Adepoju, O. T. (2015).Proximate and mineral composition of plantain (Musa Paradisiaca) wastes flour; a potential nutrients source in the 
formulation of animal feeds. African

Journal of Food Science and Technology, 6 (2), 53-57.

[27] Kavitha, S. \&Parimalavalli, R. (2014).Effect of processing methods on proximate composition of cereal and legume flurs. Journal of Human Nutrition \& Food Science, 2(6), 1-5.

[28] Fagbohun, E. D. \& Oluwaniyi, T. T. (2015). Mycoflora, proximate composition and nutritional changes during the storage of Oryza sativa. Food Science and Quality Management, 40, 108-116.

[29] Paynor, K. A., David, E. S. \& Valentino, M. J. G. (2016). Endophytic fungi associated with bamboo as possible sources of single cell protein using corn cob as a substrate. Mycosphere, 7 (2), 139147.

[30] Adegbehingbe, K. T., Adeleke, B. S. \&Fakoya. S. (2017). Solid substrate fermentation of african bush mango (Irvingia gabonensis) seeds. Journal of Advances in Microbiology, 3(1), 1-9.

[31] Khodanazary, A., Hajimoradloo, A. \& Ghorbani, R. (2013). Influence of solid-state fermentation on nutritive values and enzymatic activities of anchovy kilka (Clupeonellaengrauli formis Svetovidov, 1941) meal by using different microorganisms. International Research Journal of Applied and Basic Sciences, 4 (8), 2357-2367.

[32] Khan, N., Ruqia, B., Hussain, J., Jamila, N., Rahman, N. U. \& Hussain, S. T. (2013). Nutritional assessment and proximate analysis of selected vegetables from parachinarkurram agency. American Journal of Research Communication, 1(8), 184-198.

[33] Galila A. M. A., Darwish A. A., Bakr, B. \& Abdallah, M. M. F. (2012). Nutritional value upgrading of maize stalk by using Pleurotus ostratus and Saccharomyces cerevisiae in solid state fermentation. Annals of agricultural Science, 57(1), 47-51.

[34] Belewu., M. A., Ahmed, O. \& Ibrahim, S. O. (2011). Solid state fermentation of Jatropha curcas kernel cake with cocktail of fungi. International $J_{1} 34 \quad l$ of Bioscience, 1 (1), 12-19. 